\title{
Rio Branco, grand strategy and naval power
}

Rio Branco, grande estratégia e poder naval

http://dx.doi.org/10.1590/0034-7329201400302

JOÃO PAULO ALSINA JR. *

Rev. Bras. Polít. Int. 57 (2): 9-28 [2014]

\section{Introduction}

José Maria da Silva Paranhos Jr., Baron of Rio Branco, epitomizes Brazilian nationalism. ${ }^{1}$ Despite the impenetrable personality that motivated Nabuco to call him a "Sphinx," his political and diplomatic legacy, especially with regard to the demarcation of national borders, is revered as of great importance for the construction of the international identity of Brazil. Although much has been written about the character and his legacy, it seems clear the laudatory character of the vast majority of those narratives. Given the author's dissatisfaction with this state of affairs and out of respect for the memory of Itamaraty's patron, I intend to address an issue that lies at the heart of a series of distortions about the meaning of Paranhos Jr.'s diplomacy: the role of naval power in the broader context of the grand strategy implemented during Rio Branco's administration as chancellor.

Few periods could be classified as more fruitful with regard to building a national grand strategy than the decade in which the Baron served as foreign minister (1902-1912). Constituting the paradigmatic moment in which Brazilian Republican foreign policy was consolidated, Rio Branco's administration was able to wield the power available to the country to set, on favorable terms, the boundaries of the nation. It should be noted that Rio Branco was a contemporary and supporter of one of the greatest efforts to incorporate naval armament in Brazilian history_-the result of which was the so-called " 1910 Fleet." The analysis of the participation of the patron of diplomacy in this process, as well as his view on the use of military power in support of foreign policy, will be crucial to

* Brazilian Ministry of External Relations, Brasília, DF, Brazil (joao.alsina@itamaraty.gov.br).

1 "Baron", "Baron of Rio Branco", "Rio Branco", and "Paranhos Jr." refer to José Maria da Silva Paranhos Jr. 
determining essential elements of the Brazilian grand strategy in that historical moment. $^{2}$

Section 1 of this article touches upon the dependence of historians on State institutions in Brazil. Section 2 tries to operationalize the concept of grand strategy, while section 3 describes the consequences for the Navy of the Revolt of the Armada. The next section outlines the domestic factors affecting Brazil's capacity to react to foreign threats. Section 5 deals with the contextual elements that framed the naval reorganization programs of 1904 and 1906. In sections 6 and 7, I sketch the contours of the naval programs, Rio Branco's role in this process and the instrumentality of the new fleet for Brazil's grand strategy as implemented by the patron of national diplomacy. The last section presents the conclusions.

\section{History and officialism in Brazil}

The study of history in newly independent Brazil was directly linked to the interests of the monarchical state. There is no need to go any further in order to identify the origins of two plagues that have been ravaging national historiography, to a greater or lesser extent, since the foundation of IHGB (1838) until the present: historiographical officialism and Brazilian intelligentsia's dependence on state institutions. The permanence of this tradition was mentioned by José Honório Rodrigues 141 years after the beginning of IHGB's activities and almost half a century after the institutionalization of the social sciences in local universities: "We have a real history and an official history that oppose each other. (...) The historiography (in Brazil) has always been more or less an official historiography (...)" (Rodrigues 2010, 341). Mota corroborates this view by claiming that national historiographical production is traditionally "courtesan" (Mota 1975, 2). The combative history proposed by the former professor of Rio Branco Institute aimed to attack one of the most persistent myths disseminated by officialist historians: the bloodless nature of Brazilian history. Rodrigues would assert that his work sought to call into question the officialist mythology: "I wanted to denounce the fraud of the bloodless and cordial (...) postulate. What I intended to refute was the thesis of the bloodless process and cordiality as permanent historical behaviors of the Brazilian people" (Rodrigues 1982, 16). At the center of Rodrigues's rationale was the nationalist ideology, which drove him to reject the view that Brazilians would be invariably passive before the elites' arbitrariness.

2 There is no intention to imply that Brazilian grand strategy was determined by one man alone-someone who was not the head of the Executive branch. Nor would it be plausible to assume that Rio Branco's acts were in dissonance with the directives issued by the President and the political coalition which supported him. Therefore, Rio Branco's grand strategy, broadly speaking, can be viewed as representing the grand strategy of the country. 


\section{Grand strategy: a tentative operational concept}

This section intends to trace the inescapable contours of grand strategy and clarify the theoretical and conceptual framework adopted in the article. The case study on Baron of Rio Branco's grand strategy and the naval modernization program of the first decade of the twentieth century will generate hypotheses about the theory's adequacy to the empirical and contextual evidences presented. Turning to the operationalization of the concept of grand strategy itself, it should be considered that the grand strategy of any state involves at least the following internal factors: political, economic, ideological, institutional, cultural, geographical, technological, role of leaders, and civil-military relations. The literature on the subject does not normally attach paramount importance to the last element. However, it has crucial importance in any context, in particular when we are dealing with states where the barracks' role in domestic politics and the construction of nationality is relevant-like in many countries of Latin America. The nature of civil-military relations has multiple implications on the following aspects: military doctrine, quality of the strategic assessment of opportunities and threats, strategic culture, interface between foreign and defense policies, defense policy's degree of internal coherence, and ultimately the very political stability of the regime. To make matters even more complex, except for the geographical factor, all others interact with the international system in different ways and with different intensities.

Given the above-mentioned, it is adopted here a modified version of neoclassical realism, which postulates the interdependence between the domestic and international levels. The latter, however, does not present itself to decisionmakers in an absolutely clear fashion in terms of the incentives it offers. Incentives will be read by decision-making elites and their supporters according to a series of filters: political, ideological, institutional, inter alia. More than that, the willingness and ability to respond to the messages perceived as emanating from the international system will depend on, among other factors, the consensus among elites, the cohesion among elites, the vulnerability of the government/regime, and the social cohesion of a given state (Schweller 2006) - not to mention the quantum of material power available to substantiate a possible reaction. Despite grand strategy being related to the possibility of using force, it is not limited to it. It is also worth noting that the grand strategy of small and medium powers will be substantially constrained by the risks and opportunities emanating from its regional surroundings. In the same vein, it is essential to include in the above mentioned analytical framework the role of leaders and the ideologies they are imbued with. This is especially relevant to the work developed here, taking into account that the period corresponding to Rio Branco's administration and the naval modernization program was characterized by a very distinct zeitgeist to the one we know today. 


\section{The Revolt of the Armada and the annihilation of the naval force}

According to Rui Barbosa, three factors contributed decisively to Custódio de Melo's attempt to overthrow the florianista dictatorship: 1) the perception that Floriano Peixoto would not convene presidential elections, thus trying to perpetuate himself in power-as it is possible to infer from Floriano's veto on September 5, 1893, the eve of the naval revolt, of the legislative project that had determined the ineligibility, for one successive term, of Vice Presidents that took office due to the vacancy of the presidency; 2) federal government's continued fight against "federalist" opposition in Rio Grande do Sul state, despite promises of peaceful settlement of the local dispute made by Floriano to de Melo; and 3) Floriano's intention to override the authority of the Naval Council of Investigation and judge Admiral Wandenkolk in a military court of the Army and his inflexibility to backpedal on the compulsory retirement of the admirals involved in the episodes of April 1892.

The Revolt of the Armada, which eventually blended together with the Federalist Revolution of RGS in the face of common goals (fighting against Floriano's dictatorship), had significant internal and external repercussions. Besides instilling fear in the capital's population in view of the threats of shelling made by the bulk of the Navy's warships, the Revolt produced a strong impression in the international community. According to Joaquim Nabuco's narrative, the key factor that determined the defeat of the Navy was the intervention of foreign powers (Nabuco, 2010). Wanting to avoid the damage to international trade produced by the blockade of Rio de Janeiro's port, and interested in protecting their citizens living in Brazil's main city, the foreign squadron led by the U.S. prevented Custódio de Melo's naval forces, at first, and the fleet led by Saldanha da Gama, later, from seriously threatening the government-objective which could only be achieved through an amphibious landing, a blockade of the country's international trade, or by means of the systematic shelling of the capital by the rebellious fleet.

The consequences of the Revolt would be felt for many years. The author of Balmaceda himself would point out that the most worrying byproduct of the Revolt was to be found in the military camp-in addition to the ruin of the naval force and its resentment of the Army-because of the subversion of hierarchy resulting from the Iron Marshall's decisions. Due to the political fractures registered in the ranks of the Armed Forces, Floriano opted to employ junior officers loyal to him as interventors in the country's states. Thus, captains, majors, and lieutenant colonels were elevated from day to night to positions of power, often at the expense of higher rank officers. This process has eroded the backbone of the Army, undermining the fundamental principle of hierarchy. The "florianismo" also left deep marks in the naval force. The future Navy Minister of Rodrigues Alves, admiral Júlio César de Noronha, was one of the officers who remained equidistant from the rebel movement, being a staunch florianista (Arias Neto, 2001). Alexandrino de 
Alencar, in turn, commanded the battleship Aquidabãa, flagship of the leader of the revolt, and opted to take refuge in Argentina once Custódio de Melo and Saldanha da Gama were finally defeated (Dias, 1910).

In the same year the Revolt of the Armada broke out, Rio Branco was invited by Floriano Peixoto to take over the defense of Brazil in the arbitration of the question of Palmas (or Missions) against Argentina, to be decided by the President of the United States. It should be noted, in line with Santos's argumentation, that the opportunity given by the jacobin President to the convict royalist was convergent with the latter's efforts to seek a convenient insertion in a regime which he bitterly deplored (Santos, 2012). Ironically, the leader of the "Republic of the Sword" was responsible for opening the gates of prestige to the Baron whose reputation would have been certainly enviable during the reign of Pedro II were it not for his scandalous relationship (by the standards of the time) with a Belgian "choriste" (Viana Filho, 1959). Therefore, if the Empire's moral rigidity hindered his political rise, the Republican shortage of critical mass specialized in boundary issues provided Paranhos Jr. with the chance to become one of the great demiurges of Brazilian nationalism.

\section{Domestic factors and the failure to respond to external threats}

There is no doubt that the Brazilian grand strategy during the first 13 years of the Republic suffered from significant constraints. According to the scheme proposed by Schweller, there were problems in all four dimensions: consensus among elites, cohesion among elites, government/regime vulnerability, and social cohesion. To these dimensions, which affect the willingness and ability to respond to pressures emanating from the international system, one must add economic and financial troubles. Roughly speaking, one can divide the 1889-1902 period into two distinct phases. The first corresponded to the military presidencies. During the first five years of the Republic, the marshals-presidents sought to improve the Armed Forces' status in terms of wages and armament. Until the "Encilhamento" financial crisis this policy had been possible due to consistent economic growth. Between 1892 and 1894, however, macroeconomic conditions deteriorated while the country plunged into a very serious civil war (Federalist Revolution and Revolt of the Armada). In this context, the strengthening of diplomatic relations with the United States represented a true lifeline. At that time the "Colossus of the North" was taking the first steps of its expansive international policy. The U.S. intervention to curb the naval revolt led by Custódio de Melo and Saldanha da Gama was an actual test for this new external orientation. According to the Brazilian perspective, a close relationship with Washington offered the possibility of instrumentalizing both its economic - the world's main consumer market for national exports of coffee- and security dimensions - inculcating in the minds of regional antagonists the idea that the U.S. would aid Brazil in case of conflict. 
Alongside the careful cultivation of the relationship with the most powerful country in the hemisphere, Brazil tried not to antagonize Argentina. Rio de Janeiro's government sought to keep superficially cordial relations with its neighbor from the River Plate region. In reality, substantial portions of the Brazilian elites were disturbed by the growth of Argentine power. Two other important issues would be part of Brazil's international agenda in this period: support for European immigration - with the aim of securing the arms necessary for the development of coffee plantations - and maintenance of external sources of financing the national economy via loans, lines of credit etc. Finally, attempts were made to demarcate the national borders through direct negotiations and — when these were unfeasible-by recourse to arbitration.

With regards to the ability of the Armed Forces to support the national grand strategy, it appears that despite the efforts made by Deodoro and Floriano the dissensions between the Navy and Army, as well as the politicization of their ranks, eroded their meager combatant capabilities. Brazil was actually devoid of any significant military resources. Worse than that: those existing had become useless in the face of the systemic inability of the naval and land forces to use them effectively. The staff shortages were also conspicuous, since the military service in Brazil still had not managed to untie itself from its characteristic of an appendage of the penal system. From any angle of observation the capacity of the Armed Forces to ensure the defense of the homeland was minimal— the problem being more acute in the Navy than in the Army because of the technological content and capital intensity required by naval forces. This reality did not allow room for maneuver, forcing Brazil to adopt a moderate and juristical posture in its international relations - that, however, did not deter Floriano from exerting strong pressure on Montevideo in order to prevent the use of Uruguayan territory as safe haven for federalist revolutionaries (Bueno, 1995).

In the second phase, which corresponds to the governments of Prudente de Morais and Campos Sales, additional constraints to the implementation of a more ambitious grand strategy would be observed. Trying to ensure governability, civilian elites carried forward a policy of seclusion of the Armed Forces from party politics - either by cooptation of military leaders or by weakening the Navy and Army, particularly the latter. Economic stagnation, coupled with a financial crisis, was repeatedly invoked as justification for low military budgets. Domestic instability, especially during Prudente de Morais's government, was another critical factor that explained Brazilian self-absorption. However, the litigations over the island of Trindade and Palmas region, respectively with United Kingdom and Argentina, would be indicative of the tensions that could arise from the international system. Counting with the British lack of interest in the first case and with the deft political leadership of Rio Branco in the second, the country managed to emerge victorious in two controversies that could have contributed to foster further instability. 
Only in Campos Sales administration the Republic would build mechanisms to stabilize the operation of the polis. The term of the second President hailing from São Paulo was marked by the emphasis on recovering the credibility of the Brazilian currency-obtained by blood and iron, thus causing severe consequences for the real economy. The startup of the "governors' policy" allowed Sales to generate the necessary stability to carry forward his fiscalist program. The administration's general direction of supporting immigration to coffee plantations and advancing in the process of demarcation of the national borders remained intact. Again, Rio Branco was a key actor in leading the victorious Brazilian team in the arbitration of the controversy of Amapá. In this respect, it seems that to the French acceptance of the unfavorable outcome contributed the increasing assertiveness of the United States in the Western Hemisphere-as well as rising tensions in the old continent, which made it difficult to Paris divert its attention from threats emanating from France's immediate vicinity.

In this context, low investments in defense would result in the deepening of the crisis installed in the barracks, particularly after the Revolt of the Armada (Navy, 1893-1894), and the disaster of Canudos (Army, 1897). In view of this reality, and after the satisfactory resolution of the issue of Palmas, Brazil continued adopting what Hilton called "holding action" regarding Argentina: public manifestations of friendliness accompanied by strict surveillance of Argentine actions in South America. The decay of the Navy, however, represented not only the impossibility of staving off attacks from the sea. In some professional and political circles, a certain nostalgia for the top spot that the naval force occupied in the region during most of the nineteenth century became consolidated. Rui Barbosa, known for his verve, called the attention of the country to the annihilation of the Navy (Barbosa, 1972).

There is no doubt that the domestic constraints on the country's international actions were overwhelming during the first 13 years of the Republic. In this sense, Brazilian statesmen had limited scope to take more ambitious steps in terms of foreign policy. The controversy over Acre, in turn, called again the attention of Brazilian policymakers to the fact that international relations in the era of imperialism involved substantial security risks. Faced with so much volatility and uncertainty, the Brazilian grand strategy was fundamentally limited, defensive and self-absorbed.

\section{The contextual constraints on the naval programs}

The demarcation of Rio Branco's grand strategy background allows us to analyze the domestic constraints and international pressures responsible for the birth of the naval programs of 1904 and 1906. One can legitimately assume that the modernization of the Brazilian Navy was based on the conjunction of several internal and external factors. Actually, it was the result of an unlikely alignment of stars, an event that only happens in very special circumstances and after a long 
wait. The criticisms made by Arthur Dias about the disregard Brazilian civilian elites devoted to military affairs, in particularly to naval matters, are consistent with the difficulties that the country had to face every time it needed to deploy its Armed Forces-fact that became evident in the war of the Triple Alliance against Paraguay. The worrying state of the fleet since the Empire's death throes was exacerbated by the Revolt of the Armada and the inability of Prudente de Morais and Campos Sales's governments to invest in its uplifting (Martins and Cozza, 1997).

The situation of disarray in which the Navy had plunged—its surface units were qualified by Rui Barbosa as exponents of a "virtually extinct" force (Barbosa 1972, 174) — could have been simply perpetuated in Rodrigues Alves's government, following the historical pattern of chronic underinvestment and inefficiency succeeded by spurts of investments caused by pressing needs. Why it did not happen? Why the naval program was approved and taken forward in spite of the reluctance of many politicians to spend huge sums to rebuild the Navy? A first approximation of the answers lies in Schweller's scheme. In all four dimensions proposed by this author, Brazil, from 1902, would find itself better prepared to react to the pressures of the international system. Regarding the consensus among elites, one can safely say that there was widespread perception of risks to national sovereignty emanating from the regional (e.g. outstanding border question with Peru, rivalry with an Argentina economically and militarily more powerful than Brazil, decreasing influence over Paraguay) and international levels (e.g. European and, to a lesser extent, American imperialisms). This perception was accentuated after the disputes over the island of Trindade and Acre region, instances in which portions of the national territory had been clearly threatened by the great powers. In parallel, Brazilian military inferiority in South America against Argentina and Chile was consolidated, while the potentially explosive northern borders with Peru remained under litigation. These circumstances reinforced the belief that the country could not afford to be a nullity in the field of defense.

If the cohesion among elites was far from absolute, it had been greatly enhanced since the introduction of the "governors" policy," that established a modus vivendi between the central government in Rio de Janeiro and regional oligarchies. The predominance of the states of São Paulo and Minas Gerais stabilized the oligarchic system until the temporary split represented by the election of Hermes da Fonseca in 1910. Despite the permanence of all sorts of disagreements and arbitrariness at the local level, the power sharing scheme introduced by Campos Sales was responsible for significantly increasing the Catete's Palace capacity to rally congressional support for the implementation of its governmental agenda. The maintenance of such an agreement between the federal and state spheres of government from 1902 to 1910 - period that encompasses the fulcrum of the naval programs formulation and implementation processes studied here-was crucial to lend viability to the Navy's reorganization-notwithstanding its very high cost. 
Regarding the vulnerability of the government/regime, it is clear that there was significant improvement compared to the turmoil registered in the presidencies of Prudente de Morais, on a larger scale, and Campos Sales, to a lesser extent, particularly in terms of the stability of civil-military relations. Still, from the standpoint of the civilian leadership, the involvement of members of the Army in riots during the Revolt of the Vaccine, in 1904, demonstrated the need to accelerate the professionalization of the Armed Forces, to strengthen discipline in the barracks and to remove military officers from partisan politics. Despite the aforementioned uprising, civilian elites managed to keep the barracks under control through the cooptation of military leaders on the one side, and the professionalization of the forces on the other. Efforts to provide new equipment to land and naval units fell within the context of both initiatives, serving as well to strengthen the country's foreign policy and its ability to deter external threats.

On the social cohesion factor, it can be argued that the optimism which accompanied the Rodrigues Alves's presidency, especially the resumption of economic growth and the numerous initiatives of modernization, was the expression of a significantly greater cohesion than the one registered during the previous period-characterized by extreme instability. The Army, for instance, was able to gradually decouple the image of the military service from the notion that it was a mere gear of the criminal justice system — culminating in the adoption of the law of the draft in 1908. In contrast, this process did not seem to have had a similar effect in the naval force, where the lack of adequately educated and skilled seamen served as a justification for the maintenance of corporal punishments on board the fleet's ships — with the disastrous consequences that would surface in 1910 during the Revolt of the Whip. However, between 1890 and 1910, there was a slight improvement in literacy rates and the number of students enrolled in schools. Per capita income and the degree of urbanization also increased moderately, but noticeably.

Finally, the state of the national economy, another critical factor for the materialization of any robust reaction to threatening external stimuli, no longer posed an insurmountable obstacle to the reorganization of the Navy. Notwithstanding the significant improvement in macroeconomic conditions, the narrative about the need for financial austerity was an important axis of the governmental agenda during Alves administration (1902-1906). One also has to consider the problems generated by the overproduction of coffee and the consequent fall of the value of this commodity in the international markets. In the same vein, one just need to analyze the content of the opinion on the 1904 naval program issued by the Navy and War Committee of the House of Representatives to realize how the concerns with the high costs foisted on the public treasury constituted a decisive element (Noronha, 1950). In view of the foregoing, we should conclude that economic constraints continued to exist, but no longer persisted prohibitive circumstances preventing the reconstruction of the national fleet. 


\section{Rio Branco and naval reorganization}

Dealing specifically with the participation of Rio Branco in the formulation of the naval programs, it is quite clear, based on the contextual and empirical evidence available, that the patron of Brazilian diplomacy, contrary to a certain inaccurate narrative widespread in the Navy, had no appreciable role in their conformation. This becomes obvious from the examination of the personal correspondence of Paranhos Jr. He would tell Domício da Gama, with a mixture of disappointment and impatience, that: "(...) I was neither heard about the first naval program nor about the second” (Guedes 2002, 325). Still, Paranhos Jr.'s immense prestige and his deep connection with the Armed Forces were important factors to warrant political backing to the modernization plans of both the Navy and the Army (McCann, 1984). One can speculate, based on counterfactual reasoning, that the eventual opposition to those plans by the Brazilian foreign minister would have created serious difficulties for their implementation.

Despite Rio Branco's strong support to the reconstitution of Brazilian naval power, it must be admitted that his immediate concerns were not related to the academic debate on the best composition of the new squadron, but to the prompt acquisition of warships that would allow the country counter pressing threatsparticularly the disputes with Peru around the demarcation of the common border and with Argentina for regional hegemony. Guedes's article reveals this reality by showing the failed attempts of Rio Branco to sensitize his colleagues from the Navy (first Júlio de Noronha and then Alexandrino de Alencar) for the need to carry out spare purchases of warships. However, these demarches collided with one of the main desideratum of the naval force: acquiring a balanced and homogeneous fleet in terms of its fighting units. This could only occur if the vessels were built from scratch based on these guiding principles. The above mentioned divergence of perspectives resulted in the prolongation of the nation's military inanity in a very sensitive moment of its foreign relations. Rio Branco himself made this clear in a letter to Alexandrino de Alencar (Guedes 2002, 319).

Once approved by Congress, Alexandrino's program quickly progressed. The original contract with Armstrong Shipyards, signed in July 1906 by Noronha's administration, was canceled and a new one signed with the same company on February 20, 1907 (Topliss 1988, 246). The project of dreadnought type battleship chosen by the Navy was the 494A. The Minas Gerais class would displace 19,280 tons, develop maximum speed of 21 knots and have $12305 \mathrm{~mm}$ and 45 caliber guns as main armament. At the moment the Brazilian warships started to be built, only Britain (Bellerophon class, 18,800 tons) and the United States (Michigan class, 16,000 tons) had similar vessels under construction. The German Empire would soon follow with the Nassau class (18,900 tons), launched in June 1907. To spread out expenditures, the third battleship, Rio de Janeiro, would have its construction postponed until the Minas Gerais had been launched. 
The two dreadnoughts being built for the Brazilian Navy were the most powerful battleships of their time. Of the $12305 \mathrm{~mm}$ guns, 10 could be fired simultaneously to port or starboard and 8 toward the stern. The argument used by minister Noronha in favor of $254 \mathrm{~mm}$ guns - their higher rate of fire- to justify the effectiveness of the 14,750 tons battleships initially ordered fell apart before the model of 12-inch guns adopted in British dreadnoughts. These were capable of firing two rounds per minute, which vindicated the thesis defended by Alexandrino that modern big guns (from $254 \mathrm{~mm}$ ) had firing rates very similar to each other. Another aspect highlighted by Afonso Pena's Navy minister was the need of ensuring maximum efficiency in the use of public funds when acquiring warships. For the naval architect of the 1906 program, a country like Brazil could not afford to constantly update its fleet - circumstance which advised the acquisition of the most modern naval means possible with the aim of extending the time span of their military validity (Dias 1910, 203).

The naval reorganization program envisioned by Alexandrino, dubbed "To the Sea," was in line with the generality of the strategic thinking of the period. Regardless of the influence exerted by British shipyards on the Brazilian Navy, the trend of increasing displacement of warships was a fact of reality. It is clear that the former senator from the state of Amazonas was right to prefer a smaller number of more powerful ships to the six included in the 1904 program (3 small battleships and 3 small armored cruisers). In the prevailing conditions of the second half of the first decade of the twentieth century, the Brazilian battleships included in Júlio de Noronha's program would certainly lag behind the state of the art. Regarding the replacement of armored cruisers for extra-fast scouts of about 3,000 tons, international experience also seemed to support their adoption. The scouts acquired by Alexandrino, capable of developing 27 knots, were among the most advanced of their time. Besides serving as the fleet's main reconnaissance units, they would perform an important role in combating enemy destroyers. Given the extent of the Brazilian coast and South Atlantic's rough character, the torpedo boats of 400 tons envisaged in the 1904 program would be less seaworthy than the 650 tons ones included in the 1906 program. Aspect correctly pointed out by Souza e Silva was that any naval raid against Brazil would be executed by higher tonnage vessels_ since small torpedo boats could hardly follow a hostile fleet at great distances (Martins and Cozza, 1997). Therefore, Brazilian destroyers would face not only the enemy's capital units, but also their larger displacement destroyers - assumption that justified the adoption of a single type of heavier destroyers.

What undoubtedly constituted an error of the Alexandrino program was the non-incorporation of a coal ship, an important element for the logistic support of the fleet during larger operations. Moreover, the mining and hydrographic vessels that would substitute the coal ship were never acquired. Even more serious was the inability of the Navy to form qualified personnel to properly man the units 
acquired. This circumstance had tragic consequences, as summarized in the Revolt of the Whip in November 1910. Anyway, one cannot reproach Afonso Pena's Minister of the Navy for lack of ambition. Rather, his ambition seems to have been excessive, going far beyond the strict limits imposed by the deficiencies prevalent in that branch of the Armed Forces.

Another aspect to be highlighted is that the international context experienced by Brazil did not allow for dilettantism. At that time, there were serious threat perceptions which propelled the country to seek the acquisition of the best means of defense in the shortest amount of time. Under these conditions, Brazil did not consider acquiring a coastguard, but a combatant squadron. However, due to the nation's stage of development the local absorption of complex technologies became impractical given the fragility of the industry and innovation system. Even the maintenance of the equipment acquired often had to be done by foreign experts or abroad. In summary, the use of the defense material acquired was not considered as a tool to achieve developmental goals, but for its paramount destination: combat.

The deferral of the expenditures on the last battleship of the program made it possible to initiate the construction of two scouts and ten destroyers. According to Alexandrino de Alencar, Armstrong Shipyard has agreed to redo the design of the battleships at no cost, receiving in exchange the order for two extra-fast cruisers (scouts). These constituted enhanced versions of the English Adventure class, having a unit cost of $£ 328,500$ - which included the necessary ammunition to operate the platform (Ministério da Marinha 1908, 175). The contract for the scouts was signed in May 1907. It is worth mentioning that their propulsion would be based on turbines, a novelty for the Brazilian Navy. In parallel, the government opened up a tender, won by Yarrow Company (Scotland), for the construction of 10 destroyers. Each ship would cost $£ 73,000$, which did not include the ammunition - bought, in part, from the Armstrong group (Ministério da Marinha 1908, 176).

Regardless of the evidence that naval authorities favored British firms, it must be admitted that the procedures adopted by Alexandrino's administration were more conscientious than his predecessor's when it comes to ordering the new warships. While in 1904 the construction program would be divided by types of ship-Congress initially authorized only the purchase of battleships-, in 1906 the Navy built the three main types simultaneously. This would allow the fleet to form a coherent tactical unit, with the following configuration: one battleship backed by one armored scout and five destroyers. According to the timeline of implementation outlined by the Brazilian Congress, Alexandrino expected the final phase of the program to be completed in the next presidency, with the construction of the third cruiser, one mining ship and three submarines (Dias 1910, 176). 


\section{Rio Branco, grand strategy and naval power}

As a symbolic continuer of the Empire's foreign policy in the Republic, Rio Branco intended to assert Brazil as the first power of South America. This desideratum would not be achieved by dint of words, but by the country's capacity to perform concrete deeds. It should be noted that, through a distinct rhetorical route in relation to the one underlying the diplomatic work of the Viscount of Uruguay, Rio Branco's wish would serve after all to differentiate Brazil from the set of Hispanic states surrounding it. For this goal to materialize, an unavoidable challenge to be overcome was the settlement, in safe and permanent bases, of the not yet demarcated borders of the country. The consolidation of the fatherland's borders involved serious dangers, particularly in a period of history in which recourse to war was common currency in international relations. This process, conducted masterfully by the patron of diplomacy, entailed the threat of use of force by Brazil and by several of the countries with which it negotiated the settlement of border disputes. In line with Sávio's remark, the fact that certain historical events have not redounded to open conflict is far from meaning that the paths leading to the resulting bloodless outcomes were exempt from serious threats (Sávio, 2009).

The deletion of the conflictual elements that followed the actions of Paranhos Jr. in his quest for the final design of the body of the nation has been a major disservice rendered by officialism to the understanding of Brazil's grand strategy during the long passage of Rio Branco as head of the Ministry of External Relations. This work of concealment had the inevitable consequence of minimizing the role played by the Armed Forces in the broader context of the foreign policy of the period studied in this article. Rodrigues argues that "(...) the armed forces represent a very important role in the history of Brazil. Since independence. It was them that established, by force or show of force, the unity and the national integrity" (Rodrigues 2010, 352). In Paranhos Jr.'s view, Brazil needed to have military power commensurate with the challenges faced by his diplomatic efforts in the intricate negotiations that had been unfolding with several neighboring states. More than that, the possession of powerful Armed Forces had become essential to deter Argentina, the only South American nation that possessed actual conditions to rival Brazil for regional preeminence. Rio de Janeiro's military inferiority visà-vis Buenos Aires - deepened by the crises that followed the establishment of the Republic in 1889-acquired extremely inconvenient contours for the foreign policy of Rio Branco. Both with regards to the insecurity generated by the possible use of superior force against the country and in terms of the belittling of the Brazilian capacity to project its prestige in the region and internationally.

Although the Navy's reorganization program was not formulated in conjunction with the foreign ministry, it was instrumental to the grand strategy pursued by Rio Branco. Its implementation would make Brazil return to the 
condition enjoyed for much of the imperial regime: the first maritime power in South America. The squadron designed by Alexandrino de Alencar, as well as the one conceived by Júlio de Noronha before him, generated a strong negative reaction in Argentina's nationalist circles. In spite of this fact, there is no record of any action of Rio Branco in order to placate Argentine fears through the discussion, not to mention the acceptance, of a naval equivalence agreement. Rather, Paranhos Jr. was a staunch supporter of the program, knowing the disastrous significance for his policy of the eventual capitulation to pressures from Buenos Aires. It must be noted that the strengthening of the Navy would be convergent with the other great pillar of Brazil's strategy, which was to foster a pragmatic rapprochement with the United States. A prosperous, stable, and strong Brazil could consolidate itself as a privileged interlocutor of the largest industrial economy in the world. This strategy would allow Rio de Janeiro to play the role of a special broker between South American countries.

The quest for rapprochement with the "Colossus of the North" was compatible with the national interests not only in terms of prestige, but also economically, commercially, and in the field of defense. The support that Brazil gave to the Monroe Doctrine and the Roosevelt Corollary intended to reinforce the political ties between the two countries. These bonds would serve three main foreign policy goals: leverage the international prestige of the country, deter possible interventions of the European imperialism and increase the potential costs of any project of aggression against Brazil by neighboring nations-especially Argentina and, to a lesser extent, Peru. Establishing a special relationship with the U.S., Rio Branco hoped to obtain Washington's informal seal of approval for the country to exert influence over South America without interference. The intimate relationship between the two giant states of the Americas was particularly relevant to Brazil, to the extent that Argentina sought to expand its regional influence with renewed intensity after the Pactos de Mayo, in 1902, which normalized its relations with Chile. Initially devoid of economic and military resources that could rival those of Buenos Aires, Rio de Janeiro was left to make up for this deficiency with the support of the foremost power in the hemisphere- the greatest importer of Brazilian coffee.

Another central aspect of the grand strategy adopted between 1902 and 1912 has to do with the maintenance of the balance of power in the Platine region. In line with the policy adopted by the grandees of the Conservative Party, Paranhos Jr. sought to preserve the independence of Paraguay and Uruguay and maintain Brazil's influence on Asuncion and Montevideo. The Paraguayan revolution of 1904 and the subsequent passage of that country to the Argentine orbit represented a substantial foreign policy setback in a moment when the Navy was completely devoid of means to lend credibility to a more robust action in favor of pro-Brazilian forces in the Guarani state. Therefore, it is not surprising that Rio Branco adopted a posture of neutrality regarding the internal disputes of the two states mentioned above. This neutrality would not be absolute, since it included instructions for 
Brazilian diplomatic representatives to favor the rulers in power. The fleet of 1910 , contrary to the chancellor's claims aiming to appease Argentina, would allow the country to increase its presence in the Platine theater-particularly through the use of Pará class destroyers. This was exactly the case of the mission fulfilled by the destroyer Rio Grande do Norte in the context of the Paraguayan crisis of 1911-1912.

Despite the strengthening of the Brazilian position in the River Plate basin through the use of the destroyers of 600 tons, the squadron based in large dreadnoughts had an unequivocal vocation to perform offensive oceanic operations involving the destruction of the enemy fleet. Adopting the prevailing standard doctrine in the major navies of the world (mahanian), there is no doubt that the units incorporated in 1910 emitted clear signals to Buenos Aires. The surface units acquired in Britain would not serve to patrol the national coast, something absurd when one thinks about the costs involved in the deployment of warships displacing 19,280 tons and carrying a crew of nearly 1,000 men, but to neutralize an opponent naval force, block maritime trade, and harass the enemy's coastal cities. At this point, it is worth mentioning the tension between two basic elements of Brazil's grand strategy during the time of Rio Branco. If, on the one hand, the goal was to deter foreign powers, to the extent that there were no aggressive designs neither the intention to acquire new territories, on the other, the magnitude of the new naval assets raised fears in Argentina about discrepancies between Rio de Janeiro's discourse and actual design.

In fact, the tensions pointed out above were almost inevitable because the dispute for regional hegemony was their foundation. Even before the change in direction produced by the rise of Alexandrino de Alencar to the leadership of the naval force, Buenos Aires had been preparing to meet the challenge represented by the reorganization of the Navy proposed by Júlio de Noronha. In this context, the exhortations of Rio Branco about the peaceful sentiments nurtured by Brazilians were perfectly consistent with the strategy of appeasing Argentina while the national situation of military inferiority lasted. It should be noted that one of the arguments used by Rio Branco to justify his uncompromising opposition to any proposal of equivalence of armaments was that Brazil had respected the decisions of neighboring Argentina and Chile when they began an arms race in the 1890s due to their border disputes. Although the argument was true on a superficial level, it hid a clear fact: Rio de Janeiro's silence did not occur out of respect for the principle of sovereign autonomy of states, but due to its total incapacity to respond to that process in view of the disorganization of the economy and very serious domestic dissensions prevailing during the period. It is also worth mentioning that while still a young politician and journalist, interested in defending the purchase of military equipment by the cabinet led by his father, in the face of a war scare with Argentina in the aftermath of the conflict with Paraguay, Paranhos Jr. would declare: "No great nation can be indifferent to the armaments of neighboring states" (Pereira 2012, 160). 
The grand strategy of Rio Branco, based on the consolidation of borders, international projection of Brazilian prestige, achieving hegemony in South America, and deterrence of interventions from European imperialism depended on the reinforcement of the country's military power, particularly its naval power. As the greatest symbols of the strength of a nation and its status on the global stage, the dreadnoughts fulfilled the role of totems of an ascending and powerful Brazil. In the formulation devised by the chancellor, it was essential to inculcate in the foreign public opinion the perception of Brazil as a power in which political stability, economic progress, financial responsibility, and the solidity of state institutions prevailed. Thus, the acquisition of the Minas Gerais and São Paulo battleships was functional to the image of the nation Rio Branco wanted to disseminate internationally. However, none of this would be possible if Paranhos Jr. had taken the Ministry of External Relations before the governments of Rodrigues Alves and Afonso Pena. The existence of favorable domestic conditions was crucial for the viability of the grand strategy he would eventually implement.

Rio Branco's strategy, in which the military had a key role, suffered from the inherent weaknesses of a peripheral and backward country like Brazil in the early twentieth century. The bitter experiences of the Revolt of the Whip and "salvações" made patent how fragile the balances were in a nation fractured by serious social, economic and regional divides. The failure of the Navy's reorganization program demonstrated the need for the country to transcend mere ostentatious appearances. In this sense, it becomes evident how painful for Rio Branco it should have been to realize that a substantial part of his grand design found no support in the lugubrious Brazilian reality. The missed opportunity in 1910 represented one of the most conspicuous examples of how Brazilian diplomacy would have to act independently of effective military backing throughout the twentieth century. It must be emphasized, however, that this was by no means the desire of Paranhos Jr. Within his sphere of action, he has made every possible effort to strengthen the military with a view to obtaining for Brazil the primacy in South America.

\section{Conclusion}

As shown above, Rio Branco's actions were not based on any deontological ethics, much less did they stem from any attachment to abstract legal formulae. Paranhos Jr. was a skillful political operator, a master of the art of the possible, an exceptional juggler of contradictions. It is understandable, therefore, why his legacy lends itself to such disparate interpretations. In line with Kissinger's reflection, one can safely sustain that Rio Branco adopted the same kind of praxis of Bismarck-grounded in an empiricist conception of politics as opposed to its rationalist counterpart (Kissinger, 1968). However, a crucial difference should be pointed out at the factual level. Bismarck had behind him the most powerful army in the world, while Rio Branco could not count with remotely similar forces. In this 
context, Paranhos Jr's moderation had to do with the narrow limits imposed by the weaknesses of the Navy and Army and the specificities of the South American theater.

The grand strategy implemented between 1902 and 1912 was ambitious and involved high political and economic costs, being only possible in a permissive domestic context (accelerated modernization, economic growth, institutional stability etc.) aligned with an environment of significant international pressures (intense perception of threats). The prevailing ideologies in the period also converged around encouraging the appreciation of the Armed Forces as indispensable instruments to the survival of the state in a world where social darwinism was widespread and war a commonplace mechanism for resolving disputes. It is noteworthy that Paranhos Jr. did not exempt himself from the task of strengthening the Navy and Army, acting forcefully in favor of the modernization of the naval and land forces.

As still occurs today, there was no alignment between the general direction of foreign policy (pro-American) and the acquisition of materiel by the Armed Forces. The analysis of the naval programs of 1904 and 1906 underlines the Navy's immense degree of autonomy in determining its own force structure-which generated serious tensions in the relationship between Brazil and Argentina. Truth be told, it does not seem correct to state that the acquisition of the dreadnoughts Minas Gerais and São Paulo was solely responsible for the deterioration of relations between Rio de Janeiro and Buenos Aires. Already in 1904, Argentine military planners intended to respond to Noronha's program with the aim of preserving the naval supremacy enjoyed by their country. One could say that Alexandrino's program imposed a worrisome deterioration of the future strategic circumstance of Argentina, given the magnitude of the new Brazilian squadron designed. However, the basis of what would be the brief but intense race to the battleships in the Southern Cone was the struggle for regional hegemony. The permanence of the rivalry between the two nations in subsequent decades corroborates this assumption.

If the mismatch between the Ministry of External Relations and Navy in the design phase of the program leading to the 1910 Fleet was certain, the implementation of Alexandrino's naval reorganization would enable the country to achieve the main goal set by the Baron's foreign policy: reposition Rio de Janeiro as the greatest naval power in the subcontinent, a key element for the pursuit of regional hegemony by Brazil. The results of this process have been mixed. In addition to increased tensions with Buenos Aires, the Revolt of the Whip destroyed $a b$ ovo the possibility of employing the Navy, renewed in its surface units, as an instrument of deterrence and prestige. From a positive perspective, it can be said that the naval program of 1906 proved inexistent in the DNA of Brazilians a dominant gene inhibiting their ability to respond to threats from the international system. The naval reorganization not only showed Brazil was willing to counter 
the perceived threats, but revealed a collective desire for national aggrandizement. Therefore, it represented an important milestone of patriotism, a relevant element inserted in the broader context of the country's grand strategy in a rare moment of its history, in which domestic and international variables converged in order to push forward a substantial project of modernization of the Armed Forces. In the naval realm, the coincidence between the timing of that alignment of the stars and the launch of HMS Dreadnought allowed Brazil to project itself internationally, albeit fleetingly, as the third power in the world to incorporate this type of warship.

The elements alluded to above lead us to the drama of the Armed Forces in Brazil. This drama did not begin yesterday, as demonstrated by the case study of the naval reorganization program of the first decade of the twentieth century. The great irony resulting from the comparison of Rio Branco's era with the current one is what might be called inversion of polarities. 100 years ago, the elites led by Rio Branco endeavored to strengthen sea and land forces without realizing the narrow limits imposed by reality. A century later, a much less restrictive reality is accompanied by misconceptions about the instrumentality of military power that, after all, lead to the same outcome: the indigence of Brazil in one of the most relevant fields to any country willing to influence the direction of the international system. Even more ironic is the fact that Paranhos Jr., one of the most hardened supporters of the Brazilian build-up, has been transformed by the officialist reception of his tactical placating propaganda into an icon of present days' sterile Kantianism.

The great tragedy that derives from the narrative developed in this work is the realization of the deep misunderstanding of the role played by the Armed Forces by the ruling elites of the nation. Brazil will only become a developed country when it is capable of breaking the circular traps of backwardness prevailing in various sectors of national life. Nowadays, one of these traps engulfs defense policy. There will be no substantive progress if we are not able to know the past to build the future. The historical reconciliation of civilians and soldiers, an open work in the making, necessarily includes the correct appreciation of the international role of the Navy, Army and Air Force in a context of vigorous democracy. They will be our development shield, if we are able to understand that this concept is not compatible with the misrepresentation of the primary role of military institutions - whose number one function must be the defense of the homeland and of its international interests.

\section{Bibliographic references}

ARIAS NETO, José Miguel. (2001) Em busca da cidadania: praças da Armada nacional, 1867-1910. Tese de doutorado. Departamento de História, Faculdade de Filosofia, Letras e Ciências Humanas, Universidade de São Paulo.

BARBOSA, Rui. (1972) Cartas de Inglaterra. São Paulo: Livraria Editora Iracema. 
BRASIL. Ministério da Marinha. (1908) Relatório do ano 1907 apresentado ao Presidente da Republica dos Estados Unidos do Brazil.

BUENO, Clodoaldo. (1995) A República e sua Politica Exterior (1889 a 1902). São Paulo: Unesp.

DIAS, Arthur. (1910) Nossa Marinha: notas sobre o renascimento da marinha de guerra do Brazil no quatriennio de 1906 a 1910. Rio de Janeiro: Liga Maritima Brazileira.

GUEDES, Max Justo. (2002) O Barão do Rio Branco e a Modernização da Defesa. In: CARDIM, Carlos Henrique, ALMINO, João (orgs.). Rio Branco, a América do Sul e a Modernização do Brasil. Rio de Janeiro: EMC.

KISSINGER, Henry. (1968) The White Revolutionary: reflections on Bismarck. Daedalus, Vol. 97, No. 3, Summer, p. 888-924.

MARTINS, Hélio Leôncio, COZZA, Dino Willy. (1997) Poderes Combatentes. In: Vários Autores. História Naval Brasileira (vol.5, tomo I B). Rio de Janeiro: Serviço de Documentação da Marinha.

MCCANN, Frank. (1984) The formative period of Twentieth-Century Brazilian Army Thought, 1900-1922. Hispanic American Historical Review. 64, (4), p. 737-765.

MOTA, Carlos Guilherme. (1975) A Historiografia Brasileira nos Últimos Quarenta Anos: Tentativa de Avaliação Crítica. Debate \& Crítica, No. 5, março, p. 1-26.

NABUCO, Joaquim. (2010) A Intervenção Estrangeira durante a Revolta da Armada de 1893. Brasília: Senado Federal.

NORONHA, Júlio César de. (1950) A Organização Naval. Rio de Janeiro: Imprensa Naval.

PEREIRA, Manoel Gomes (org.). (2012) Obras do Barão do Rio Branco X: artigos de imprensa. Brasília: FUNAG.

RODRIGUES, José Honório. (1982) Conciliação e Reforma no Brasil: um desafio históricocultural. Rio de Janeiro: Nova Fronteira.

RODRIGUES, José Honório. (2010) José Honório e Nós. In: MOTA, Carlos Guilherme. História e contra-história: perfis e contrapontos. São Paulo: Globo.

SANTOS, Luís Cláudio Villafañe G. (2012) O Evangelho do Barão: Rio Branco e a Identidade Brasileira. São Paulo: Unesp.

SÁVIO, Domingos. (2009) Território e negócios na "Era dos Impérios": os belgas na fronteira oeste do Brasil. Brasília: Funag.

SCHWELLER, Randall. (2006) Unanswered Threats: Political Constraints on the Balance of Power. Princeton: Princeton University Press.

TOPLISS, David. (1988) The Brazilian dreadnoughts, 1904-1914. Warship International, v. XXV, No. 3, p. 240-289.

VIANA FILHO, Luiz. (1959) A Vida do Barão do Rio Branco. Rio de Janeiro: José Olympio.

Submitted May 6, 2014

Accepted May 7, 2014 


\section{Abstract}

This article addresses Baron of Rio Branco's grand strategy and the role played by the naval reorganization program (1904-1910) in this context. The ensuing case study determined the domestic and international constraints that affected the program, as well as the worldview of the patron of Brazilian diplomacy regarding military power's instrumentality to foreign policy.

Keywords: Baron of Rio Branco; grand strategy; naval power.

\section{Resumo}

Este artigo aborda a grande estratégia do Barão do Rio Branco e o papel que o programa de reorganização naval (1904-1910) desempenhou nesse contexto. O estudo de caso realizado determinou os condicionantes domésticos e internacionais daquele programa, assim como a mundivisão do patrono da diplomacia brasileira a respeito da instrumentalidade do poder militar para a condução da política externa.

Palavras-chave: Barão do Rio Branco; grande estratégia; poder naval. 